\title{
PENERAPAN MODEL PEMBELAJARAN LEARNING CYCLE 5E UNTUK MENINGKATKAN KEMAMPUAN PEMAHAMAN KONSEP MATEMATIS SISWA
}

\author{
Ika Sriyanti ${ }^{1}$, Timbo Faritcan Siallagan ${ }^{2}$, Eva Novia Triani ${ }^{3}$ \\ $1,2,3$ STKIP Subang \\ 1 ikasriyanti99@gmail.com \\ 2 timbo.siallagan@yahoo.co.id \\ ${ }^{3}$ evanoviatriana@gmail.com
}

\begin{abstract}
ABSTRAK
Penelitian ini dilatarbelakangi karena kemampuan siswa dalam memahami konsep matematika yang masih kurang, dengan anggapan siswa bahwa pelajaran matematika adalah pelajaran yang sulit. Salah satu alternatif pembelajaran yang bisa digunakan untuk meningkatkan pemahaman konsep matematis siswa adalah pembelajaran dengan menggunakan model pembelajaran Learning Cycle 5E. Tujuan yang ingin dicapai dalam penelitian ini adalah untuk mengetahui peningkatan pemahaman konsep matematis siswa yang mendapat pembelajaran dengan menggunakan model pembelajaran Learning Cycle $5 E$ lebih baik daripada siswa yang mendapat pembelajaran konvensional dan sikap siswa terhadap pembelajaran Learning Cycle 5E. Penelitian ini menggunakan kuasi eksperimen. Populasi dalam penelitian ini adalah siswa kelas VII SMP Negeri 2 Dawuan, diambil dua kelas dari kelas sebagai sampel penelitian yaitu kelas VII B dan VII I. Instrumen yang digunakan dalam penelitian ini terdiri dari tes dan non tes berupa angket. Setelah dilakukan tes berupa tes tertulis yaitu Pretest dan Posttest dapat diperoleh hasilnya yaitu kelas eksperimen yang mendapatkan pembelajaran dengan menggunakan model Learning Cycle 5E mengalami peningkatan 69\%, sedangkan kelas kontrol dengan pembelajaran menggunakan model pembelajaran Konvesional mengalami peningkatan sebesar 48\%. Maka peningkatan kemampuan pemahaman konsep matematis siswa kelas eksperimen lebih baik secara signifikan dibandingkan kelas kontrol. Dari hasil analisis angket siswa sebagian besar siswa kelas eksperimen menunjukan sikap positif dalam pembelajaran matematika yang menggunakan model Learning Cycle 5E.
\end{abstract}

Kata Kunci : Learning Cycle 5E, Konvensional, Pemahaman matematis

\begin{abstract}
This research is motivated by the lack of students 'ability to understand mathematical concepts, with students' assumption that mathematics is a difficult subject. One alternative learning that can be used to improve students' understanding of mathematical concepts is learning by using the Learning Cycle $5 E$ learning model. The objective to be achieved in this research is to find out the increase in understanding of mathematical concepts of students who get learning by using the Learning Cycle Learning model $5 \mathrm{E}$ is better than students who get conventional learning and student attitudes towards learning Learning Cycle 5E. This research uses quasi-experimental. The population in this study were eighth grade students of SMPN 2 Dawuan, two classes were taken from the class as research samples, namely class VII B and VII I. The instruments used in this study consisted of tests and non-tests in the form of questionnaires. After doing the test in the form of a written test that is Pretest and Posttest the results can be obtained that the experimental class that gets learning using the Learning Cycle 5E model has increased $69 \%$, while the control class with learning using conventional learning models has increased by $48 \%$. Then the increase in the ability to understand mathematical concepts of experimental class students is significantly better than the control class. From the results of student questionnaire
\end{abstract}


analysis most of the experimental class students showed a positive attitude in mathematics learning using the 5E Learning Cycle model.

Keywords: 5E Learning Cycle, Conventional, Mathematical understanding.

\section{PENDAHULUAN}

Menurut kamus besar bahasa indonesia secara Terminologi Pendidikan adalah sebuah proses ataupun tahapan dalam pengubahan sikap serta etika maupun tata laku seseorang atau kelompok orang dalam meningkatkan pola pikir manuasia melalui pengajaran dan pelatihan serta perbuatan yang mendidik. Menurut Thompson Pendidikan merupakan pengaruh kuat terjadinya perubahan pada setiap jati diri manusia. Kemudian yang menghasilkan pemikiranpemikiran serta penalaran setiap manusia yang berbeda. Dengan hal itulah pendidikan dapat berjalan dan ilmu pengetahuan dapat berkembang.

Matematika merupakan suatu ilmu yang terintegrasi dengan baik antar konsepnya, dengan ilmu lain, maupun dengan kehidupan sehari-hari. Sebagai seorang pendidik, guru haruslah berperan untuk membimbing peserta didik dalam menerapkan konsep-konsep matematika dan kemampuan berpikir matematika yang telah mereka pelajari kedalam masalahmasalah yang berkaitan atau dikenal dengan kemampuan pemahaman konsep matematis. Zulkardi (2003:7) mengatakan bahwa "mata pelajaran matematika pada konsep"Oleh karena itu agar siswa dalam belajar matematika lebih berhasil siswa harus lebih banyak diberi kesempatan untuk melihat kaitan-kaitan itu. Untuk mewujudkan semua itu, maka tujuan pendidikan harus dicapai secara maksimal. Pencapaian tujuan sangat tergantung bagaimana proses pembelajaran. Metode pembelajaran sangat mempengaruhi proses pembelajaran, sehingga guru harus dapat memilih metode mengajar yang lebih tepat dengan kondisi dan situasi pada saat proses pembelajaran berlangsung. Menurut Sanjaya (2009) indiktor pemahaman konsep diantaranya: (a) mampu menerangkan secara verbal mengenai apa yang telah dicapainya; (b) mampu menyajikan situasi matematika kedalam berbagai cara serta mengetahui perbedaan; (c) mampu mengklasifikasikan objek-objek berdasarkan dipenuhi atau tidaknya persyaratan yang membentuk konsep tersebut; (d) mampu menerapkan hubungan antara konsep dan prosedur, mampu memberikan contoh dan kontra dari konsep yang dipelajari; (e) mampu menerapkan konsep secara algoritma; (f) mampu mengembangkan konsep yang telah di pelajari. Kurangnya pemahaman konsep matematika menjadi salah satu yang sering banyak ditemui yaitu Kemampuan siswa yang tidak memahami konsep matematika akan menimbulkan kesulitan 
siswa dalam mempelajari matematika. Seharusnya siswa harus lebih aktif dalam pembelajaran matematika dan yang paling utama siswa memahami pemahaman konsep dalam matematika, dan siswa sebagai penemu yang aktif menemukan berdasarkan pengalamannya. Tingkat rendahnya hasil belajar dalam pemahaman konsep matematika bukan hanya disebabkan matematika sulit melainkan juga diakibatkan oleh beberapa faktor, antara lain berkaitan dengan model pembelajaran yang digunakan oleh guru. Faktor lain yang dapat mempengaruhi rendahnya pemahaman konsep matematika siswa adalah terdapat banyak anak-anak yang setelah belajar matematika bagian yang sederhana banyak yang tidak dipahaminya, banyak konsep yang dipahami secara keliru.

Sedangkan menurut Soekanto (dalam Ngalimun, 2016:7) model pembelajaran merupakan kerangka konseptual yang melukiskan prosedur yang sistematis dalam mengorganisasikan pengalaman belajar untuk mencapai tujuan belajar tertentu dan berfungsi sebagai pedoman bagi para perancang pembelajaran dan para pengajar dalam merencanakan aktivitas belajar mengajar. Agar konsep-konsep matematika dapat tersampaikan dengan baik pada siswa, pembelajaran tidak terlepas dari kemampuan guru menerapkan model pembelajaran. Pengembangan model pembelajaran yang tepat pada dasarnya bertujuan untuk menciptakan kondisi pembelajaran yang memungkinkan siswa dapat belajar secara aktif dan menyenangkan, sehingga siswa dapat memahami konsep-konsep matematika dengan baik. Pada proses pembelajaran, guru pelu menetapkan suatu model pembelajaran, upaya yang dapat dilakukan adalah dengan menggunakan model pembelajaran yang melibatkan siswa secara langsung dalam pembelajaran. Dari beberapa model pembelajaran matematika, salah satu model pembelajaran yang menekankan keaktifan siswa dalam suatu proses pembelajaran yaitu model pembelajaran Learning Cycle.

Model pembelajaran Learning Cycle pertama kali diperkenalkan oleh Robert Karplus dalam Science Curriculum Improvement Study/SCIS (Ngalimun, 2017). Learning Cycle patut dikedepankan, karena sesuai dengan teori belajar Piaget (Renner el at dalam Ngalimun, 2017), teori belajar yang berbasis kontruktivisme. Hal ini terlihat pada sebagian besar materi yang diajarkan pada saat pembelajaran berlangsung siswa tidak berani untuk menanyakan kesulitan dalam memahami materi maupun dalam mengerjakan soal yang diberikan oleh guru. Inisiatif siswa sangat kurang, hal tersebut nampak ketika guru memberi kesempatan siswa untuk bertanya maupun berpendapat tidak dimanfaatkan oleh siswa dengan baik. 
Menurut Wena (2014; 170) Model pembelajaran Learning Cycle 5E memiliki 5 tahap: pembangkit minat (engagement), ekplorasi (eksploration), penjelasan (explanation), elaborasi (elaboration), dan evaluasi (evaluation). Siswa tidak hanya mendengar keterangan guru tetapi dapat berperan aktif untuk menggali, menganalisis, dan mengevaluasi pemahamannya terhadap konsep-konsep matematika yang dipelajari, sehingga siswa dapat memahami konsep-konsep matematika dengan baik. Sikap siswa terhadap model pembelajaran Learning Cycle adalah siswa lebih aktif dalam proses pembelajaran, serta dengan aktifnya siswa dalam pembelajaran siswa dapat menguasai kompetensi-kompetensi yang harus dicapai dalam tujuan pembelajaran, dan mendorong siswa untuk menjelaskan ide-ide atau pendapat mengenai suatu konsep dengan kalimat dan pemikiran sendiri. Maka dari itulah didalam suatu kelompok siswa dituntut untuk membuat hubungan yang baik antar anggota kelompok sehingga sikap untuk menghargai sesama dan saling membantu sangatlah diperlukan. Menurut Purwanto (2011), mengatakan bahwa Sikap senantiasa mempunyai hubungan tertentu dengan objek dengan kata lain, sikap itu terbentuk, dipelajari atau berubah senantiasa berkenaan dengan suatu objek tertentu yang dapat dirumuskan dengan jelas. Sikap siswa sebagai penunjang dalam mencapai suatu tujuan, sikap dipengaruhi perasaan pendukung atau tidak mendukung terhadap suatu objek. Sikap positif cenderung siswa lebih tekun dalam belajar sehingga mencapai hasil yang memuaskan sehingga dapat mendukung siswa dalam mempelajari matematika. Dan sebaliknya, siswa yang mempunyai sikap negatif tidak akan bersemangat belajar sehingga hasilnya kurang memuaskan sehingga menghambat dalam belajar. Berdasarkan analisis hasil penelitian pembelajaran matematika di SMP Negeri 2 Dawuan peneliti bekerja sama dengan guru matematika SMP Negeri 2 Dawuan yang berupaya untuk mencari penyelesaian dalam pembelajaran matematika dengan menerapkan model pembelajaran Learning Cycle $5 E$ untuk meningkatkan kemampuan pemahaman konsep matematis siswa yang belum pernah dilaksanakan di kelas VII B SMP Negeri 2 Dawuan. Dengan demikian diharapkan pemahaman konsep matematis siswa meningkat dan sikap siswa terhadap pembelajaran Learning Cycle $5 E$ bersigat positif. Berdasarkan uraian latar belakang masalah diatas, maka penulis melakukan sebuah penelitian dengan judul "Penerapan Model Pembelajaran Learning Cycle Untuk Meningkatkan Pemahaman Konsep Matematis Siswa". 


\section{METODE PENELITIAN}

Penelitian yang akan dilakukan merupakan penelitian eksperimen, dengan desain penelitian kontrol pretest-posttest. Penelitian dengan desain ini melibatkan dua kelas pengambilan sampel nya menggunakan teknis purposive sampling. Hal tersebut berdasarkan hipotesis yang telah diajukan sebelumnya, bahwa untuk menjawab permasalahan penelitian diperlukan dua kelas eksperimen dan kelas kontrol.

Populasi dalam penelitian ini adalah siswi di SMP Negeri 2 Dawuan, sampel yang diambil dalam penelitian ini adalah siswa kelas VII B sebagai kelas eksperimen yang diberikan pembelajaran matematika dengan menggunakan model pembelajaran Learning Cycle 5E dan siswa kelas VII I sebagai kelas kontrol diberikan pembelajaran matematika dengan pembelajaran konvensional. Untuk melihat perbedaan peningkatan kemampuan pemahaman konsep matematis siswa dilakukan pretest dan posttest pada dua kelas tersebut.

Instrumen penelitian yang tersusun terdiri dari : (1) tes kemampuan awal dan akhir pemahaman konsep, (2) angket untuk mengukur kemampuan pemahaman siswa, (3) lembar observasi untuk mencatat aktivitas guru dan siswa. Teknik pengumpulan data yang digunakan dalam penelitian ini meliputi teknik pengumpulan data kuantitatif dan kualitatif. Data kuantitatif adalah data yang digunakan untuk mengetahui ada tidaknya peningkatan kemampuan pemahaman konsep matematis siswa dari data hasil protes dan data posttest. Sedangkan analisis data secara kualitatif dilakukan untuk mengetahui bagaimana sikap siswa terhadap pembelajaran dengan menggunakan pembelajaran Learning Cycle 5E yakni dilakukan dengan cara pemberian angket pada kelas eksperimen.

Pengolahan data tes (data kuantitatif) dimulai dengan menganalisis hasil pretest-posttest untuk mengetahui apakah terdapat perbedaan yang signifikan kemampuan awal dan akhir pemahaman konsep antara siswa kelas yang menggunakan model pembelajaran Learning Cycle $5 E$ dan kelas yang menggunakan pembelajaran konvensional, dilakukan uji kesamaan dua ratarata pretest-posttest. Sebelum menggunakan uji kesamaan dua rata-rata pretest-posttest dengan uji T, harus diperiksa terlebih dahulu normalitas dan homogenitas data pretest-posttest kedua kelas tersebut. Jika data tidak berdistribusi normal maka data akan dianalisis dengan menggunakan uji non parametrik tanpa harus uji homogenitas, metode yang dipakai disini adalah uji Mann-Whitney sebagai media bantu uji statistik, digunakan Minitab 18 For Windows. Pengolahan data kualitatif dilakukan tes akhir, pada kelas eksperimen dilanjutkan dengan 
pengisian angket. Tujuan dari pengisian angket tersebut untuk mengetahui sikap siswa terhadap penggunaan teknik Learning Cycle $5 E$ dalam pembelajaran.

\section{HASIL DAN PEMBAHASAN}

Pada Pembahasan ini akan dijelaskan mengenai hasil dan pembahasan penelitian yang telah dilakukan di SMP Negeri 2 Dawuan. Data yang diperoleh dalam penelitian ini adalah data kuantitatif yang diperoleh skor pretest dan skor posttest kelas Learning Cycle $5 E$ maupun kelas Konvensional serta data kualitatif yang diperoleh dari hasil angket pengukuran sikap siswa terhadap pembelajaran yang menggunakan model pembelajaran Learning Cycle 5E. Data tersebut akan diolah dan dianalisis untuk menjawab rumusan masalah guna memperoleh kesimpulan terhadap hasil penelitian.

\section{Peningkatan Kemampuan Pemahaman Konsep Matematis Siswa}

Untuk menganalisis kemampuan pemahaman konsep matematis siswa sebelum dan sesudah diberi perlakuan digunakan data kemampuan pemahaman konsep yang diperoleh dari skor pretest dan skor posttest kelas Learning Cycle $5 E$ maupun kelas Konvensional. Pengolahan data kuantitatif pada penelitian ini menggunakan bantuan software Minitab 18. Berdasarkan hasil analisis deskriptif (Tabel 1) menunjukan bahwa terdapat skor rata - rata kemampuan pemahaman konsep matematis siswa sebelum dan sesudah perlakuan.

Tabel 1. Deskripsi Data Kemampuan Pemahaman Konsep

\begin{tabular}{lrrrr}
\hline \multirow{2}{*}{ Deskripsi } & \multicolumn{2}{c}{ LC5E } & \multicolumn{2}{c}{ Konvensional } \\
\cline { 2 - 5 } & Pre-test & Post-test & Pre-test & Post-test \\
\hline Rerata & 15,96 & 24,69 & 11,90 & 20,13 \\
Max & 22,00 & 27,00 & 17,00 & 25,00 \\
Min & 10,00 & 15,00 & 7,00 & 13,00 \\
SD & 3,326 & 4,133 & 2,644 & 2,822 \\
\hline Sumber: Statistik Deskriptif pre-test dan post-test & &
\end{tabular}

Berdasarkan tabel 1 diatas skor rerata hasil pretest kemampuan pemahaman konsep kelas eksperimen adalah 15,96 dengan standar deviasi 3,326 lebih tinggi dari kelas kontrol dengan rerata 11,90 dengan standar deviasi 2,644. Begitu juga dengan skor rerata posttest kemampuan pemahaman konsep pada kelas eksperimen dengan rerata 24,69 standar deviasinya 4,133 lebih tinggi dibandingkan dari kelas kontrol dengan rerata 20,13 standar deviasinya 2,844. Sekilas berdasarkan rerata skor posttest kelas eksperimen lebih baik dari pada kelas kontrol. 
Selanjutnya untuk melihat perbedaan peningkatan kemampuan pemahaman konsep matematika antara kelas eksperimen dengan kelas kontrol perlu di uji secara statistik N-Gain dengan hasil sebagai berikut.

Tabel 2. Deskriptif Data N-Gain

\begin{tabular}{cccccc}
\hline Kelas & $\mathrm{N}$ & Rata-rata & $\begin{array}{c}\text { Skor } \\
\text { Terendah }\end{array}$ & $\begin{array}{c}\text { Skor } \\
\text { Tertinggi }\end{array}$ & $\begin{array}{c}\text { Standar } \\
\text { Deviasi }\end{array}$ \\
\hline Eksperimen & 32 & 0,69 & 0,25 & 1,00 & 0,24 \\
Kontrol & 32 & 0,48 & 0,06 & 0,90 & 0,08 \\
\hline Sumber: Statistik Deskriptif Data $N$-Gain & & &
\end{tabular}

Dari hasil perhitungan N-Gain kemampuan pemahaman konsep rerata hasil N-Gain kelas eksperimen adalah 0,69 dengan standar deviasi 0,24 lebih tinggi dibandingkan dengan kelas kontrol dengan rerata 0,48 standar deviasinya 0,08 . Sekilas hasil rerata $\mathrm{N}-$ Gain kelas eksperimen lebih baik dibandingkan dengan kelas kontrol.

Selanjutnya untuk mengetahui apakah terdapat perbedaan peningkatan N-Gain kemampuan pemahaman konsep antara kelas eksperimen dengan kelas kontrol berbeda secara signifikan maka perlu dilakukan uji statistik yang digunakan. Sebelumnya terlebih dahulu dilakukan uji prasyarat normalitas untuk mengetahui berdistribusi normal atau tidak. Uji normalitas skor N-Gain dihitung dengan uji statistik Kolmogorov-Smirnov pada taraf signifikansi $\alpha=0,05$

Tabel 3. Hasil Uji Normalitas Gain Kemampuan Pemahaman Konsep

\begin{tabular}{ccc}
\hline No & Kelas & $P$-Value \\
\hline 1. & Eksperimen & 0,010 \\
2. & Kontrol & 0,102 \\
\hline
\end{tabular}

Berdasarkan Tabel 3 diperoleh hasil normalitas gain kelas eksperimen adalah 0,010 PValue $\geq \alpha$ maka H_0 ditolak, sedangkan kelas kontrol adalah 0,102 P-Value $<\alpha$ maka $\mathrm{H}_{-} 0$ diterima. Maka dapat disimpulkan bahwa dari kedua kelas tersebut untuk kelas eksperimen tidak berdistribusi normal, sedangkan untuk kelas kontrol berdistribusi normal. Setelah dilakukan uji normalitas, ternyata salah satu sampel tidak berdistribusi normal yaitu sampel eksperimen sehingga dilakukan uji Mann Whitney pada Minitab 18 for windows, dengan nilai P-Value 0,05

Tabel 4. Hasil Uji Mann-Whitney N-Gain Kemampuan Pemahaman konsep

\begin{tabular}{ccc}
\hline No & Tes & $P$-Value \\
\hline 1. & Posttest & 0,000 \\
\hline
\end{tabular}

Berdasarkan Tabel 4 diatas, diperoleh nilai P-Value adalah 0,000 , maka $0,000<\alpha$, maka dapat disimpulkan bahwa $\mathrm{H} \_1$ diterima yang menyatakan terdapat perbedaan kemampuan 
pemahaman konsep matematis siswa antara kelas eksperimen dan kelas kontrol. Artinya siswa yang memperoleh pembelajaran matematika dengan menggunakan model pembelajaran Learning Cycle $5 E$ memiliki kemampuan pemahaman konsep matematis yang lebih baik daripada siswa yang memperoleh pembelajaran konvensional.

Dari kesimpulan hasil analisis diatas secara statistik maka kelas eksperimen yang mendapatkan pembelajaran dengan menggunakan model Learning Cycle 5E mengalami peningkatan 69\% dengan kategori peningkatan tinggi. Sedangkan kelas kontrol dengan pembelajaran menggunakan model pembelajaran biasa mengalami peningkatan sebesar $48 \%$ dengan kategori peningkatan sedang, maka peningkatan kemampuan pemahaman konsep matematis siswa kelas eksperimen lebih baik secara signifikan dibandingkan kelas kontrol. Berikut akan ditunjukan hasil Posttest beberapa siswa dikelas eksperimen yang mendapat perolehan skor yang paling tinggi pada beberapa soal posttest. Terlihat pada Gambar 1 jawaban posttest nomor 7 .

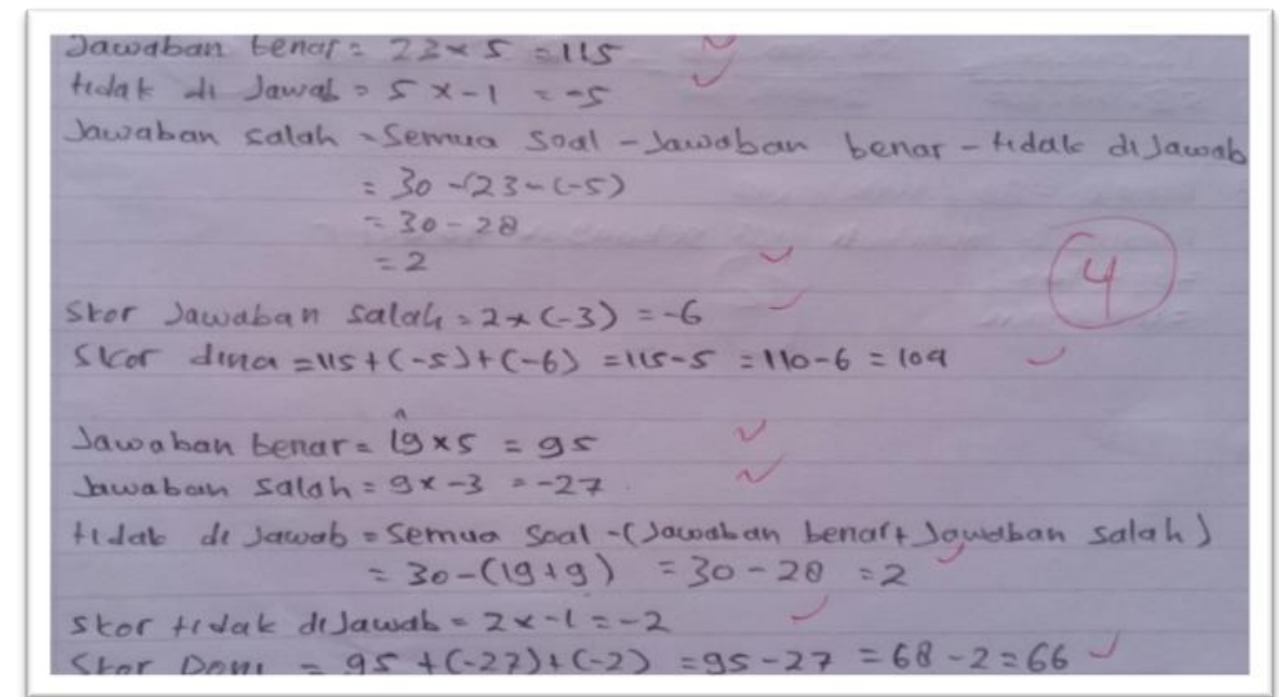

Gambar 1. Jawaban siswa pada soal posttest nomor 7

Berdasarkan Gambar 1 yang merupakan jawaban nomor 7 menunjukkan bahwa indikator kemampuan pemahaman konsep yaitu menerapkan konsep secara Algoritma yang meliputi mengidentifikasi unsur-unsur yang diperlukan sudah tercapai, serta jawaban yang benar mendapat skor 4 pada soal tersebut. 
Sikap Siswa Terhadap Pembelajaran Matematika Dengan Menggunakan Model Pembelajaran Learning Cycle $5 E$

Salah satu keberhasilan dalam proses pembelajaran matematika dengan menggunakan model Learning Cycle $5 E$ yaitu adanya sikap siswa yang positif terhadap pembelajaran dengan menggunakan model Learning Cycle $5 E$ yang dilakukan pada kelas eksperimen. Berdasarkan perhitungan skor rata-rata angket hasil siswa yang terdiri dari 15 pertanyaan dengan 9 pertanyaan positif dan 6 pertanyaan negatif yang diklasifikaskan menjadi tiga indikator yaitu, percaya diri siswa pada saat pembelajaran matematika, minat siswa terhadap pembelajaran matematika, dan kesungguhan siswa terhadap pembelajaran matematika yang menggunakan model pembelajaran Learning Cycle 5E semuanya memiliki skor diatas skala Likert atau skor rata-rata secara keseluruhannya adalah sebesar 4,02 yang dimana skor ini lebih dari 3,00. Hal ini menunjukan bahwa sikap siswa kelas eksperimen secara keseluruhan menunjukan sikap positif terhadap pembelajaran matematika dengan menggunakan model pembelajaran Learning Cycle 5E.

\section{Hasil Lembar Observasi Aktivitas Guru}

Aktivitas yang diamati observer pada Lembar Observasi Guru adalah sebagai berikut : 1) Guru mengucapkan salam sebelum memulai pembelajaran, 2) Guru mengecek kehadiran siswa, 3) Guru menyampaikan tujuan pembelajaran, 4) Guru membagi siswa dalam kelompok, 5) Guru membagi Lembar Kerja Siswa (LKS), 6) Guru menghadapkan siswa pada situasi baru (masalah), 7) Guru mengarahkan siswa untuk merumuskan jawaban, 8) Guru mengajukan persoalan kepada siswa yang sesuai yang sesuai dengan tujuan pembelajaran khusus, 9) Guru menunjuk beberapa siswa untuk menjawab pertanyaan dan menanggapi jawaban, 10) Guru membantu siswa menemukan jawaban dengan memberikan pertanyaan yang menuntun jawaban siswa, 11) Guru mengajukan pertanyaan akhir pada siswa untuk mengetahui tercapainya indikator dan materi telah dipahami oleh seluruh siswa, 12) Guru bersama siswa menyimpulkan materi bilangan bulat, 13) Guru menginformasikan materi yang akan dipelajari pada pertemuan selanjutnya, 14) Guru menutup pembelajaran. Berikut hasil dari observasi guru aktivitas guru selama empat kali pertemuan, bahwa pertemuan pertama lembar observasi aktivitas guru memperoleh rata-rata 3,3, dan pada pertemuan kedua meningkat menjadi 3,8, selanjutnya 
kembali meningkat pada pertemuan ketiga menjadi 4,1, lalu meningkat pada pertemuan keempat menjadi 4,5

\section{Hasil Lembar Observasi Aktivitas Siswa}

Hasil lembar kegiatan guru yang menggambarkan keterampilan guru dalam melakukan kegiatan pembelajaran matematika dengan menggunakan model pembelajaran Learning Cycle $5 E$ yang dilakukan oleh seorang pengamat dengan menggunakan lembar observasi guru dengan skor tertinggi untuk setiap butir observasi terhadap aktivitas siswa adalah 5 sedangka jumlah butir observasi adalah 14, maka skor maksimal yang dapat diperoleh adalah 70. Hal ini dilakukan agar guru dapat melihat kekurangannya dengan melihat hasil lembar observasi yang telah diisi oleh observer selama guru memberikan pembelajaran dengan menggunakan model pembelajaran Learning Cycle 5E sehingga guru dapat memaksimalkan pembelajaran pada pertemuan selanjutnya.

Selanjutnya aktivitas siswa yang diamati observer selama empat pertemuan adalah sebagai berikut: 1) Siswa mampu memahami situasi baru (masalah), 2) Siswa diberikan pertanyaan untuk menggali pengetahuan terkait masalah, 3) Siswa merumuskan jawaban, 4) Siswa diberikan persoalan yang sesuai dengan tujuan pembelajaran, 5) Beberapa siswa ditunjuk untuk menjawab pertanyaan dan menanggapi jawaban temannya, 6) Siswa dibantu untuk menemukan jawaban dengan pertanyaan dari guru, 7) Siswa diberikan pertanyaan akhir untuk mengetahui tercapainya indikator dan materi yang telah dipahami oleh siswa, 8) Siswa dan guru menyimpulkan materi yang telah dipelajari, 9) Siswa mendengarkan penjelasan guru terkait materi pada pertemuan selanjutnya. Dari hasil dapat dilihat bahwa rata-rata aktivitas siswa selalu meningkat pada setiap pertemuan. Untuk pertemuan pertama memperoleh rata-rata 3,0 lalu pada pertemuan kedua meningkat menjadi 3,6, dan selanjutnya kembali meningkat pada pertemuan ketiga rata-rata menjadi 4,0, dan pada pertemuan keempat rata-rata hasil observasi meningkat menjadi 4,6.

\section{KESIMPULAN}

Dari hasil penelitian ada beberapa hal yang dapat disampaikan, diantaranya adalah sebagai berikut: (1) Peningkatan kemampuan pemahaman konsep matematis siswa yang mendapatkan pembelajaran matematika dengan menggunakan model pembelajaran Learning Cycle $5 E$ lebih tinggi dibandingkan dengan siswa yang mendapatkan pembelajaran 
konvensional. (2) Sikap siswa selama pembelajaran baik pembelajaran dengan menggunakan model Learning Cycle $5 E$ berjalan dengan baik. Dalam proses pembelajaran berlangsung siswa terlibat aktif di kelas. Sehingga secara keseluruhan sikap siswa terhadap pembelajaran yang menggunakan model pembelajaran Learning Cycle $5 E$ bersikap positif.

\section{REFERENSI}

Ngalimun. (2016). Strategi dan Model Pembelajaran. Yogyakarta: Arwaja Pressindo.

Ngalimun. (2017). Strategi dan Model Pembelajaran. Yogyakarta: Dua Satria Offset. Peraturan Menteri Pendidikan Nasional RI No 22 Tahun 2006.

Romadecade. (2019). Pengertian Pendidikan adalah: manfaat, fungsi, definisi, Makna, Tujuan. [Online]. Tersedia di: https://www.romadecade.org/pengertian-pendidikan/

Purwanto, M. (2011). Psikologi Pendidikan. Bandung: Remaja Rosdakarya.

Sanjaya, W. (2009). Strategi Pembelajaran Berorientasi Standar Proses Pendidikan. Jakarta: Prenada

Wena, Made. (2014). Strategi Pembelajaran Inovatif Kontemporer. Jakarta: Bumi Aksara.

Zulkardi. (2003). Pendidikan Matematika di Indonesia: Beberapa Permasalahan dan Upaya Penyelesaiannya. Palembang: Unsri 